\title{
Cloning and transcriptional expression of a novel gene during sex inversion of the rice field eel (Monopterus albus)
}

\author{
X. C. Qu ${ }^{1 \dagger}$, J. Y. Jiang ${ }^{2,3 \dagger}$, C. Cheng ${ }^{1}$, L. Feng ${ }^{1}$ and Q. G. Liu ${ }^{1 *}$
}

\begin{abstract}
We performed annealing control primer (ACP)-based differential-display reverse transcription-polymerase chain reaction (DDRT-PCR) to isolate differentially expressed genes (DEGs) from the stage IV ovary and ovotestis of the rice field eel, Monopterus albus. Using 20 arbitrary ACP primers, 14 DEG expressed-sequence tags were identified and sequenced. The transcriptional expression of one DEG, $G 2$, was significantly greater in the ovotestis than the stage IV ovary. To understand the role of $G 2$ in sex inversion, $G 2$ CDNA was cloned and semi-RT-PCR, real time PCR were performed during gonad development. The full-length G2 cDNA was 650 base pairs (bp) and it comprised a $5^{\prime}$-untranslated region (UTR) of 82 bp, a 3'-UTR of 121 bp and an open reading frame of 444 bp that encoded a 148-amino acid protein. The expression of $G 2$ was weak during early ovarian development until the stage IV ovary, but expression increased significantly with gonad development. We speculate that G2 may play an important function during sex inversion and testis development in the rice field eel, but the full details of the function of this gene requires further research.
\end{abstract}

Keywords: Differentially expressed genes (DEGs), Ovotestis, DDRT-PCR, Hermaphroditic fish

\section{Background}

In vertebrates, sex can be determined by one of many mechanisms, including chromosomal, polygenic and environmental sex determination. There are approximately 24,000 species of fish (Nelson 1994), and examples of each mechanism exist within fish species. Indeed, in some fish, more than one mechanism can contribute to sex determination and different species exhibit various mechanisms for controlling sexual determination and patterns of sexual differentiation. The study of gender control not only has important theoretical applications, but a greater understanding of these mechanisms also has considerable practical utility. Sex determination and differentiation in fish is a very promiscuous process with respect to evolutionary patterns observed between

\footnotetext{
*Correspondence: qgliu@shou.edu.cn

${ }^{\dagger}$ X.C. Qu and J.Y. Jiang authors contributed equally to this work and should be considered co-first authors

${ }^{1}$ College of Fisheries and Life Sciences, Shanghai Ocean University, Shanghai 201306, China

Full list of author information is available at the end of the article
}

genera and families, and within individuals subjected to modifications by external factors (Devlin and Nagahama 2002; Herpin and Schart 2011). Sex determination is the genetic and environmental processes, whereas sex differentiation is the physical realization of genetic variability and environmental factors in terms of testicular or ovarian development (Baroillier et al. 1999; Nakamura et al. 1998; Uller and Helantera 2011). In contrast to the wellestablished studies on sex determination in humans and a few animals (Sinclair et al. 1990; Matsuda et al. 2002; Yoshimoto and Ito 2011; Angelopoulou et al. 2012), although a series of studies have been conducted in hermaphrodite fish over recent years (Alam et al. 2008; Zhou and Gui 2010; Nozu et al. 2009; Wu et al. 2010; Jeong et al. 2009), no breakthroughs in progress have been made to date and the molecular mechanisms that govern sex determination and differentiation in many hermaphrodite fish remain elusive. Furthermore, the genetic mechanisms of sex determination (including sex inversion) are known only for some gonochoristic fish species (Wu et al. 2012).

\section{Springer}

(c) 2015 Qu et al. This article is distributed under the terms of the Creative Commons Attribution 4.0 International License (http:// creativecommons.org/licenses/by/4.0/), which permits unrestricted use, distribution, and reproduction in any medium, provided you give appropriate credit to the original author(s) and the source, provide a link to the Creative Commons license, and indicate if changes were made. 
The rice field eel (Monopterus albus) is an economically important freshwater fish distributed widely in China, Japan and other parts of Southeast Asia (Xiao and Liu 1995a). It is a protogynous freshwater fish that exhibits an adult sex inversion from functional females to males (Liu 1944; Liem 1963; Chan and Phillips 1967; Xiao and Liu 1995b). According to Xiao and Liu (Xiao and Liu 1995a, b), the female sexual development of $M$. albus can be divided into six stages, termed I to VI. After sex maturity and ovulation is achieved, the ova and ovarian gradually degenerate. At the same time, spermatogonia begin to multiple on the germinal fold and form spermatocysts. This is the intersex development stage, and the male individual then develops from the female. The male development of $M$. albus can also be divided into different stages. This eel is commonly studied because of these unique physical characteristics.

In recent years, environmental pollution and habitat degradation in China have dramatically reduced the populations of rice field eel. Enhanced understanding of the biological mechanisms of sex inversion should help relieve the present urgent market requirements for rice field eels seedlings. In most cases, the reproductive capacity of these species is compromised, and hence the study of strategies and mechanisms involved in reproduction and sexual differentiation are central to evaluate the potential effects of contaminants. Recently, great efforts have been made to uncover the mechanism that underlies gonad sex inversion in the rice field eel, including physiological (Chu 2011; Yuan et al. 2012) and molecular aspects (Ye et al. 2007; Xiao et al. 2010; He et al. 2010, 2012; Qu et al. 2011; Huang et al. 2005). However, the mechanism of sex inversion in the rice field eels remains unclear.

Molecular biology techniques have been developed that can identify DEGs in cells under various physiological stages or experimental conditions. Difficulty often arises in identifying the gene responsible for a specialized function during a certain biological stage because the gene is expressed at low levels, whereas the bulk of mRNA within a cell is made up of highly abundant transcripts (Wan et al. 1996). Thus, to screen for low concentration DEG transcripts, PCR amplification is required. One screening method, differential-display, requires PCR using short arbitrary primers (Liang and Pardee 1992, 1995). Although this method is simple, rapid and only requires small amounts of total RNA, many investigators have experienced particularly high false-positive rates (Debouck 1995; Wan et al. 1996) and poor reproducibility of their results because of non-specific annealing of the short arbitrary primers. Recently, a new ACP DDRTPCR method has been developed, and this technology uses a specific primer type to increase both the specificity and sensitivity of the assay (Hwang et al. 2003; Kim et al. 2004).

In this present study, annealing control primer (ACP)based differential-display reverse transcription-polymerase chain reaction (DDRT-PCR), rapid amplification of cDNA ends (RACE), semi-quantitative RT-PCR, real time PCR methods were performed on ovary, ovotestis and testis stages of the rice field eel gonad in an attempt to screen for genes related to rice field eel sex differentiation and understand sex inversion. This study will provide a reference for future studies into sex differentiation of the rice field eel and other teleosts.

\section{Methods \\ Sample collection and histological observations of the gonad}

The rice field eels were captured in Chong Ming Island $\left(31^{\circ} 27^{\prime}-31^{\circ} 51^{\prime} \mathrm{N}, 121^{\circ} 09^{\prime \prime}-121^{\circ} 54^{\prime} \mathrm{E}\right)$, Shanghai, China, in September 2009. All experiments were performed in accordance with the Animal Care and Use Committee guidelines of the Shanghai Ocean University. The abdomen was slit, a small segment of the gonad was freed from the fat and mesenteric tissues, and then this was removed for histological assessment of the sexual status by routine paraffin sectioning according to the structure of the gonads. Samples for histological analysis were kept in Bouin's solution overnight before being embedded in paraffin. Cross-section $(5 \mu \mathrm{m})$ were processed and stained with hematoxylin and eosin. The remainder of the gonad sample was frozen immediately in liquid nitrogen and stored at $-80{ }^{\circ} \mathrm{C}$ for subsequent molecular analyses. At the same time, referring to the method of Zhu et al. (2010), 50-100 mg sections of gonad were fixed overnight at $4{ }^{\circ} \mathrm{C}$ in freshly prepared $4 \%$ paraformaldehyde in $100 \mathrm{mM}$ phosphate buffered saline (PBS; pH 7.4). After washing three times with PBS at room temperature, the samples were stored in methanol at $-20^{\circ} \mathrm{C}$.

\section{RNA isolation and CDNA synthesis for the ACP system}

Tissues from the stage IV ovary and ovotestis of rice field eels were dissected and snap frozen in liquid nitrogen. Total RNA was isolated (TaKaRa Mini BEST Universal RNA Extraction Kit) and then processed with deoxyribonuclease I (TaKaRa, Dalian). The total RNA was used for synthesis of the first-strand cDNA by reverse transcriptase. Reverse transcription was performed for $1.5 \mathrm{~h}$ at $42{ }^{\circ} \mathrm{C}$ in a final reaction volume of $20 \mu \mathrm{L}$ containing $3 \mu \mathrm{g}$ of purified total RNA, $4 \mu \mathrm{L}$ of $5 \times$ RT buffer, $5 \mu \mathrm{L}$ of $10 \mathrm{mM}$ dNTPs, $1 \mu \mathrm{L}$ of $10 \mu \mathrm{M}$ cDNA synthesis primer dT-ACP1 $\left(\left(5^{\prime}\right.\right.$-CTGTGAATGCTGCGACTACG

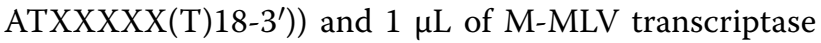
(TaKaRa). These mixtures were heated to $94{ }^{\circ} \mathrm{C}$ for $2 \mathrm{~min}$ 
Table 1 The ACP primer sequences used in this study

\begin{tabular}{|c|c|}
\hline Primer name & Sequence \\
\hline \multicolumn{2}{|c|}{ 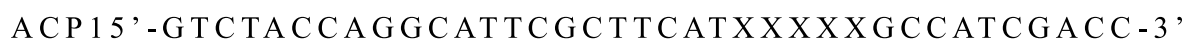 } \\
\hline \multicolumn{2}{|c|}{ 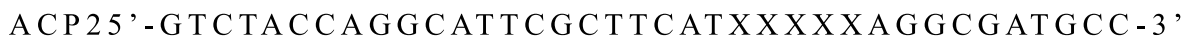 } \\
\hline \multicolumn{2}{|c|}{ A CP $35^{\prime}$ - GTCTACCAGGCATTCGCTTCATXXXXXCCGGAGGATG-3, } \\
\hline \multicolumn{2}{|c|}{ 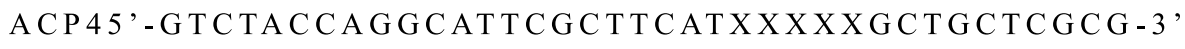 } \\
\hline \multicolumn{2}{|c|}{ ACP $55^{\prime}$ - GTCTACCA GGCATTCGCT TCATXXXXXA G T GCGCTCG-3, } \\
\hline \multicolumn{2}{|c|}{ 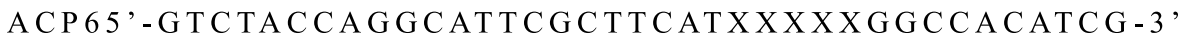 } \\
\hline \multicolumn{2}{|c|}{ 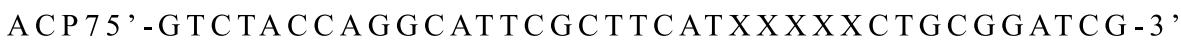 } \\
\hline \multicolumn{2}{|c|}{ ACP 85 ' - G TCTACCAGGCAT TCGCT TCATXXXXXGGTCACGGAG-3' } \\
\hline \multicolumn{2}{|c|}{ A C P 95'-GTCTACCA G GCATTCGCT TCATXXXXXGATGCCGCTG-3, } \\
\hline \multicolumn{2}{|c|}{ ACP 105 '-GTCTACCA GGCATTCGCT TCATXXXXXTGGTCG T GCC-3, } \\
\hline \multicolumn{2}{|c|}{ ACP 115 '-GTCTACCA GGCATTCGCTTCATXXXXXCT GCA GGACC-3, } \\
\hline \multicolumn{2}{|c|}{ ACP $125^{\prime}-$ GTCTACCAGGCATTCGCTTCATXXXXXACCGTGGACG - 3, } \\
\hline \multicolumn{2}{|c|}{ ACP $135^{\prime}-$ GTCTACCA GGCATTCGCTTCATXXXXXGCT TCACCGC-3, } \\
\hline \multicolumn{2}{|c|}{ ACP $145^{\prime}$ - GTCTACCAGGCATTCGCT TCATXXXXXGCAAGTCGGC-3' } \\
\hline \multicolumn{2}{|c|}{ ACP $155^{\prime}$ - G TCTACCA GGCAT TCGCT TCATXXXXXCCACCG T G T G-3' } \\
\hline \multicolumn{2}{|c|}{ ACP $165^{\prime}$ - GTCTACCA GGCATTCGCT TCATXXXXXGTCGACGGTG-3' } \\
\hline \multicolumn{2}{|c|}{ ACP $175^{\prime}$ - GTCTACCAGGCAT TCGCT TCATXXXXXCAAGCCCACG - 3' } \\
\hline \multicolumn{2}{|c|}{ ACP $185^{\prime}$ - GTCTACCAGGCATTCGCTTCATXXXXXCGGAGCATCC-3, } \\
\hline \multicolumn{2}{|c|}{ ACP195'- GTCTACCA GGCATTCGCTTCATXXXXXC TCTGCGA GC-3, } \\
\hline \multicolumn{2}{|c|}{ ACP205'-GTCTACCAGGCATTCGCTTCATXXXXXGACGTTGGCG-3, } \\
\hline
\end{tabular}

to inactivate the reaction, and the first strand cDNA samples were diluted by adding $80 \mu \mathrm{L}$ of $\mathrm{dd}_{2} \mathrm{O}$.

PCR was conducted with 20 pairs of arbitrary ACPs (Table 1) to synthesize the second strand cDNA under annealing conditions (XiangSC and Nam 2005). For the PCR reaction, ovary and ovotestis cDNA samples were used as a template for amplification using different sets of arbitrary ACPs according to the GeneFishing ${ }^{\mathrm{TM}}$ Kit (Neuro-Hemin Biotech, Hangzhou). PCR was performed in $25 \mu \mathrm{L}$ volumes containing $1 \mu \mathrm{L}$ of $\mathrm{cDNA}, 2.5 \mu \mathrm{L}$ of $10 \times$ PCR buffer, $1 \mu \mathrm{L}$ arbitrary ACP and dT-ACP, $1.5 \mu \mathrm{L}$ of $10 \mathrm{mM}$ dNTP and $0.5 \mu \mathrm{L}$ Taq polymerase (TaKaRa). After incubating at $94{ }^{\circ} \mathrm{C}$ for $2 \mathrm{~min}$, the PCR was performed at $50{ }^{\circ} \mathrm{C}$ for $5 \mathrm{~min}$ then $72{ }^{\circ} \mathrm{C}$ for $1 \mathrm{~min}$, followed by 40 cycles of $94{ }^{\circ} \mathrm{C}$ for $30 \mathrm{~s}, 65^{\circ} \mathrm{C}$ for $40 \mathrm{~s}$ and $72{ }^{\circ} \mathrm{C}$ for $1 \mathrm{~min}$, and finally $72{ }^{\circ} \mathrm{C}$ for $7 \mathrm{~min}$. PCR products were electrophoresed on $2 \%$ agarose gels and stained with ethidium bromide.

\section{Cloning and transformation}

Differentially expressed bands were cloned into the pMD$\mathrm{T}(18)$ vector (TaKaRa). In order to verify the identity of the inserted DNA, isolated plasmids were sequenced using an automated DNA sequencer by Jie Li Biology
Co., Ltd. (Shanghai, China). Complete sequences were analyzed by searching for homologous genes using the BLASTn and BLASTx algorithms in the GenBank database (http://www.ncbi.nlm.nih.gov).

\section{Semi-quantitative RT-PCR and real time PCR}

We identified a differentially expressed gene (DEG) called G2 that had greater levels of transcription in the ovotestis than the stage IV ovary, and this gene was selected to validate the ACP DDRT-PCR prescreening approach. Semi-quantitative RT-PCR and real-time PCR were performed using total RNA from the gonad (ovary at stages II, III, IV, V, VI, the ovotestis, and early and late stage testis) and other tissues (brain, heart, spleen, liver, kidney and muscle) in individual. The early stage testis contains spermatogonia and spermatocytes, while the late stage is defined once the spermatocytes have undergone meiosis and the spermatogenic cysts contain sperm or have released the sperm. First-strand cDNA was synthesized from $2 \mu \mathrm{g}$ of total RNA from each individual using oligo $\mathrm{dT}$ (18) primers (TaKaRa) and the M-MLV reverse transcriptase enzyme (TaKaRa). The RNA transcription levels of G2 were analyzed by semi-quantitative RT-PCR and real time PCR. $\beta$-actin was used as the internal control 


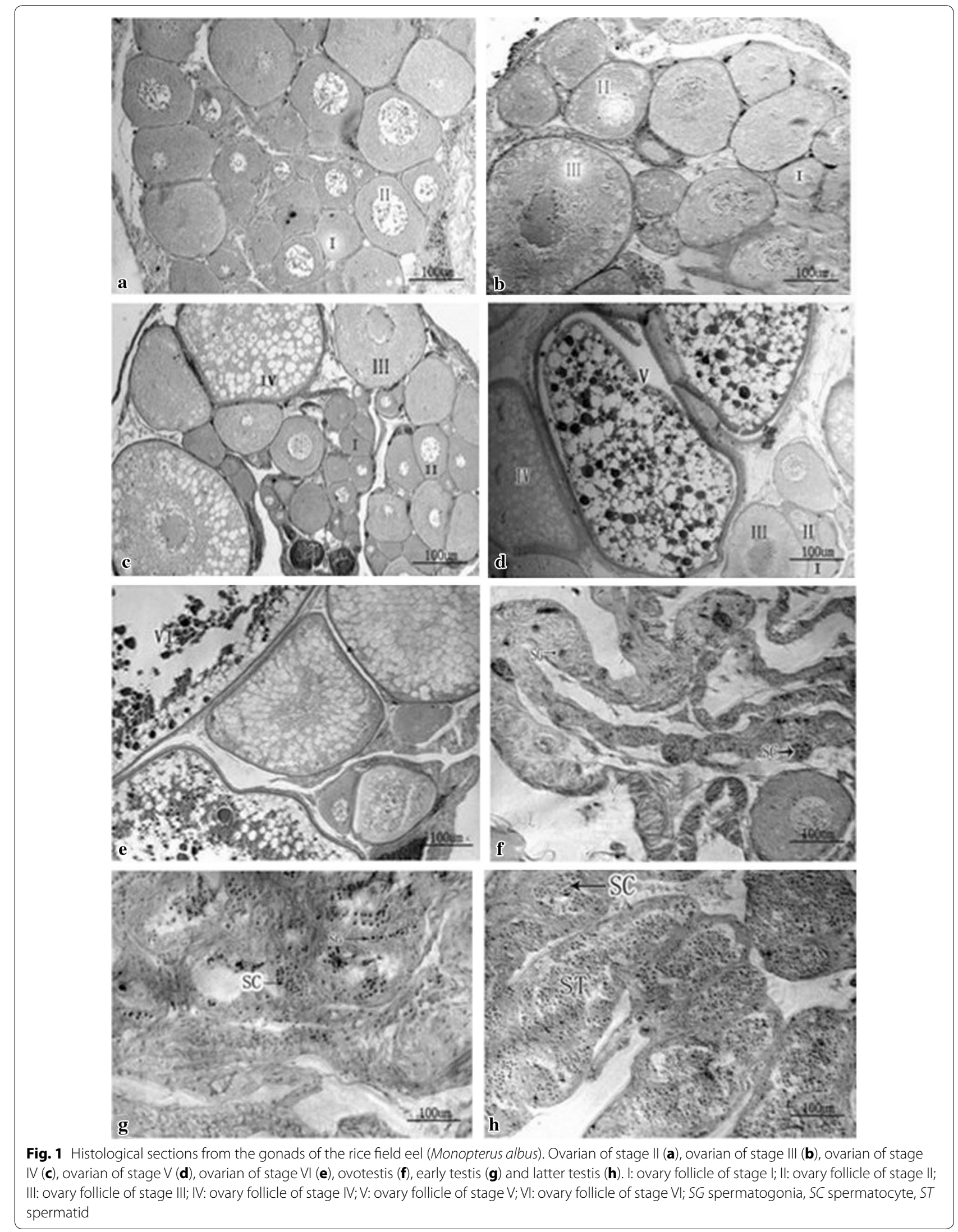



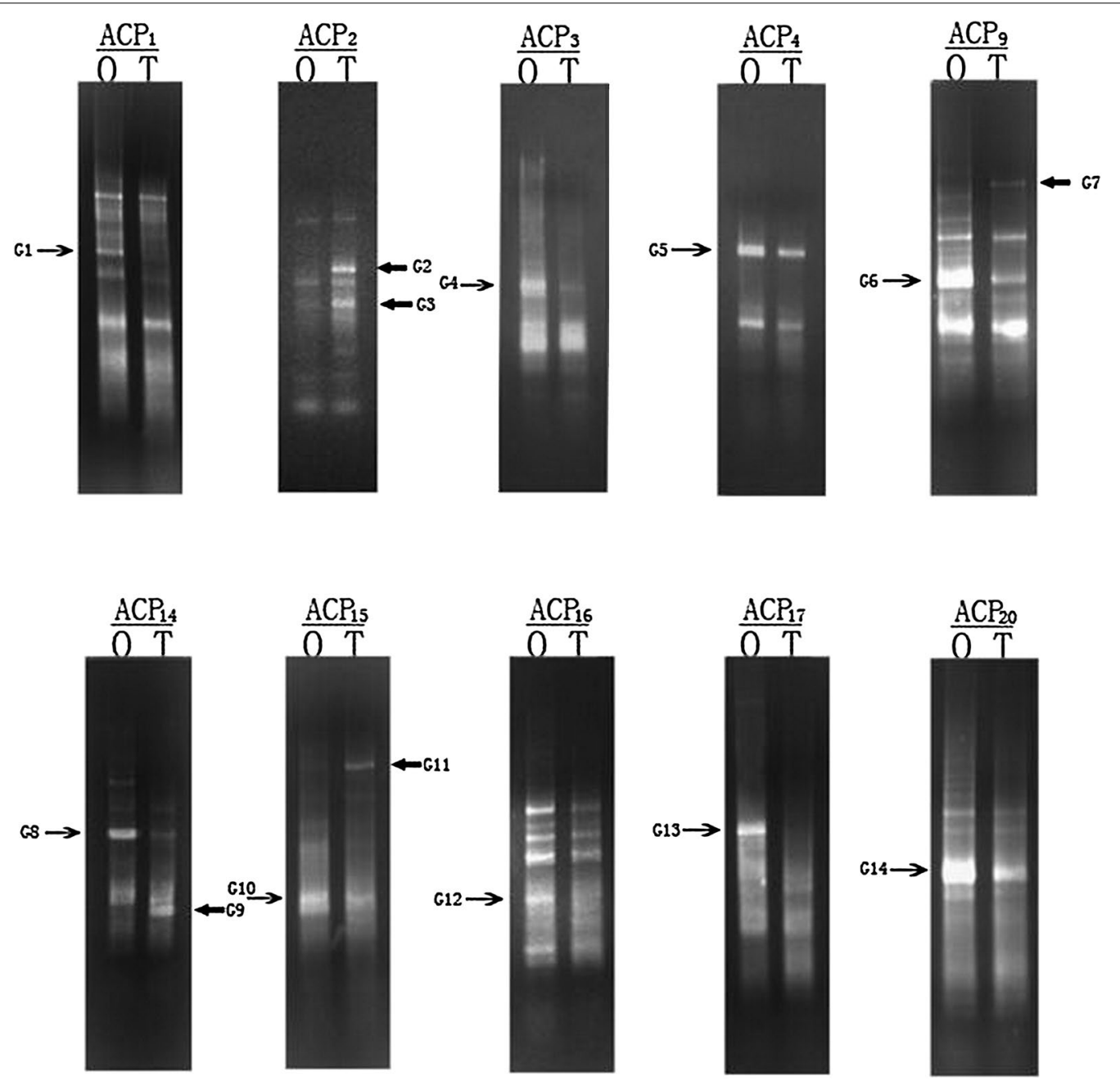

Fig. 2 The results of ACP DDRT-PCR obtained from the stage IV ovary $(\mathrm{O})$ and ovotestis $(\mathrm{T})$. O stage IV ovary, T ovotestis. The ACP DDRT-PCR products were separated on $2 \%$ agarose gel and stained with ethidium bromide. ACP1-20 indicates the arbitrary primers that were used in the ACP DDRT-PCR technique. The arrow indicates the differentially expressed genes (G1-14) identified between the stage IV ovary and the ovotestis

and muscle was the control tissue. The real-time PCR (ABI 7500) cycling conditions were as follows: $3 \mathrm{~min}$ at $95^{\circ} \mathrm{C}, 40$ cycles of $15 \mathrm{~s}$ at $95^{\circ} \mathrm{C}, 30 \mathrm{~s}$ at $60^{\circ} \mathrm{C}$, and $1 \mathrm{~min}$ at $72{ }^{\circ} \mathrm{C}$ in a $20-\mu$ l reaction mix containing $2 \times$ SYBR Green I $(10 \mu \mathrm{L})$, primers $(10 \mu \mathrm{M}), 50 \times$ Rox Reference Dye II $0.4 \mu \mathrm{L}$, cDNA Template $1 \mu \mathrm{L}(20 \mathrm{ng})$ and $\mathrm{ddH}_{2} \mathrm{O}$. The primer sequences were $5^{\prime}$-ACGGCAAG.

GTTGTGATGG-3' (G2 F); 5'-GTTATGGAAGTTGG CAGGGT-3' (G2 R); 5'-ATCGCCGC ACTCGTTGTTG AC-3' $\left(\beta\right.$-actin F); and $5^{\prime}$-CCTGTTGGCTTTGGG GTTC-3' ( $\beta$-actin R).

\section{G2 full-length cDNA amplification and sequencing}

Full-length $G 2$ cDNA was retrieved by performing $5^{\prime}$ RACE using the SMART RACE cDNA Amplification Kit and the Advantage 2 PCR Kit (Clontech). Gene-specific primers were designed according to the known expressedsequence tag (EST). The primer sequence was $5^{\prime}$-GCC ACACTTGGAACCCACAACCACAGAGA- $3^{\prime}$. Thermal cycle parameters were 25 cycles of $94{ }^{\circ} \mathrm{C}$ for $30 \mathrm{~s}, 68^{\circ} \mathrm{C}$ for $30 \mathrm{~s}$, and then $72{ }^{\circ} \mathrm{C}$ for $3 \mathrm{~min}$. The RACE products were cloned and sequenced as described above.

\section{Statistical analysis}

All values of real time PCR were processed by SPSS 17.0 software, and calculated as the $2^{-\Delta \Delta \mathrm{Ct}}$ mean \pm standard deviation. Differences between two consecutive stages of gonad development were tested using DunnettT3 software. Differences were considered significant if $\mathrm{P}$ was $\leq 0.05$ and highly significant if $\mathrm{P}$ was $\leq 0.01 . \Delta \Delta \mathrm{Ct}$ was calculated as follows: $\left(\mathrm{Ct}_{\text {target }}-\mathrm{Ct}_{\text {actin }}\right)_{\text {the gonad stage }}-$ $\left(\mathrm{Ct}_{\text {target }}-\mathrm{Ct}_{\text {actin }}\right)_{\text {the stage II ovary }}(\mathrm{Qu}$ et al. 2014). 


\section{Results}

\section{Gonad histology}

We harvested eight gonad stages from rice field eels during sex development: ovaries in stages II, III, IV, V, and VI, the ovotestis, and early and late testis (Fig. 1). Because the paraffin sections showed there were no male tissues in the stage IV ovary tissues while the spermatocytes first appeared in ovotestis, we decided to isolate DEGs from the gonad tissues at these stages.

\section{Identification of DEGs between the stage IV ovary and ovotestis tissues}

We performed ACP DDRT-PCR to identify DEGs between the stage IV ovary and ovotestis tissues using a combination of 20 arbitrary primers and two anchored oligod $\mathrm{T}_{(18)}$ primers from an ACP-based GeneFishing PCR kit (Seegen Inc.). A total of 14 DEG fragments were isolated from gels and sequenced. We identified nine down-regulated candidate genes and five up-regulated candidate genes during the sex inversion stage of the rice field eel (Fig. 2). Gene ontology annotations, BLASTN and BLASTX searches of all 14 sequences against the GenBank database revealed that nine genes had strong homology with known genes, whereas five were hypothetical genes (Table 2).

\section{Semi-quantitative RT-PCR and real time PCR of G2}

To further determine the specific transcription patterns of one DEG, G2 expression was analyzed by semi-quantitative RT-PCR and real time PCR. G2 was expressed in the brain, heart, muscle, spleen, kidney and liver (Fig. 3). On the other hand, semi-quantitative RT-PCR and real time PCR results showed that G2 was expressed at only low levels in the early developmental stages of the ovary (stages II and III), but it increased significantly and rapidly during gonad development in ovary stages IV, V and VI, the ovotestis, and early and late stages of testicular development (Figs. 3 and 4).

\section{Cloning and sequence analysis of the full-length $\mathrm{G} 2$ gene cDNA}

The RACE method was used to clone the full-length cDNA of $G 2$ (650 bp), and this was found to comprise a $5^{\prime}$-untranslated region (UTR) of $82 \mathrm{bp}$, a 121-bp $3^{\prime}$-UTR and an open reading frame of 444 bp that encoded a 148amino acid protein (Fig. 5). Similarity analysis showed that $G 2$ was a hypothetical gene with no homology to any annotated DNA sequences. It is predicted to be a nonclassical secretion protein rather than a signal peptide according to SignalP online software (http://www.cbs. dtu.dk/services/SignalP/).

\section{Discussion}

To date, attempts to screen DEGs in the rice field eel have been sparse. The identification of novel gonad specific genes to understand the sex reversal of the rice field eel is therefore of great interest. In this study, in order to characterize the transcriptome in Monopterus albus, we used the newly developed ACP DDRT-PCR method and identified 14 DEGs between the ovary and ovotestis that

Table 2 Sequence homology and characterization of differentially expressed genes

\begin{tabular}{|c|c|c|c|c|c|}
\hline Clone no. & $\begin{array}{l}\text { Fragment } \\
\text { size (bp) }\end{array}$ & $\begin{array}{l}\text { GenBank } \\
\text { homology no. }\end{array}$ & Homology & $\begin{array}{l}\text { Expression } \\
\text { pattern }\end{array}$ & Homologous gene \\
\hline G1 & 555 & AB212971.1 & $370 / 430(86 \%)$ & Down & Pagrus major imp alpha mRNA \\
\hline G2 & 408 & - & - & Up & \\
\hline G3 & 211 & - & - & Up & \\
\hline G4 & 421 & GO657149.1 & $246 / 292(84 \%)$ & Down & Yellow perch ovarian library 3, mRNA \\
\hline G5 & 745 & GR673969.1 & $338 / 405(83 \%)$ & Down & $\begin{array}{l}\text { Tilapia adult ovary library Oreochromis niloticus cDNA } \\
5 \text {,mRNA }\end{array}$ \\
\hline G6 & 479 & FD698341.1 & $351 / 490(71 \%)$ & Down & Hippoglossus hippoglossus cDNA, mRNA \\
\hline G7 & 785 & FE214073.1 & $212 / 273(77 \%)$ & Up & Dissostichus mawsoni adult liver library, mRNA \\
\hline G8 & 625 & AY614597.1 & 220/292 (75 \%) & Down & $\begin{array}{l}\text { Oncorhynchus mykiss myc-regulated DEAD box } \\
\text { protein mRNA }\end{array}$ \\
\hline G9 & 211 & - & - & Up & \\
\hline G10 & 207 & BX927294.7 & $79 / 91(86 \%)$ & Down & $\begin{array}{l}\text { Zebrafish DNA sequence from clone } \mathrm{CH} 211-222116 \text { in } \\
\text { linkage group } 13\end{array}$ \\
\hline G11 & 939 & - & - & Up & \\
\hline G12 & 266 & - & - & Down & \\
\hline G13 & 665 & EX465831.1 & $466 / 521(89 \%)$ & Down & Lates calcarifer cDNA clone LBE39E07 5-, mRNA \\
\hline G14 & 467 & EB506952.1 & $119 / 142(83 \%)$ & Down & $\begin{array}{l}\text { Striped sea bream hepatic library Lithognathus mor- } \\
\text { myrus CDNA, mRNA }\end{array}$ \\
\hline
\end{tabular}

Up up-regulated candidate genes during sex inversion, down down-regulated candidate genes during sex inversion 


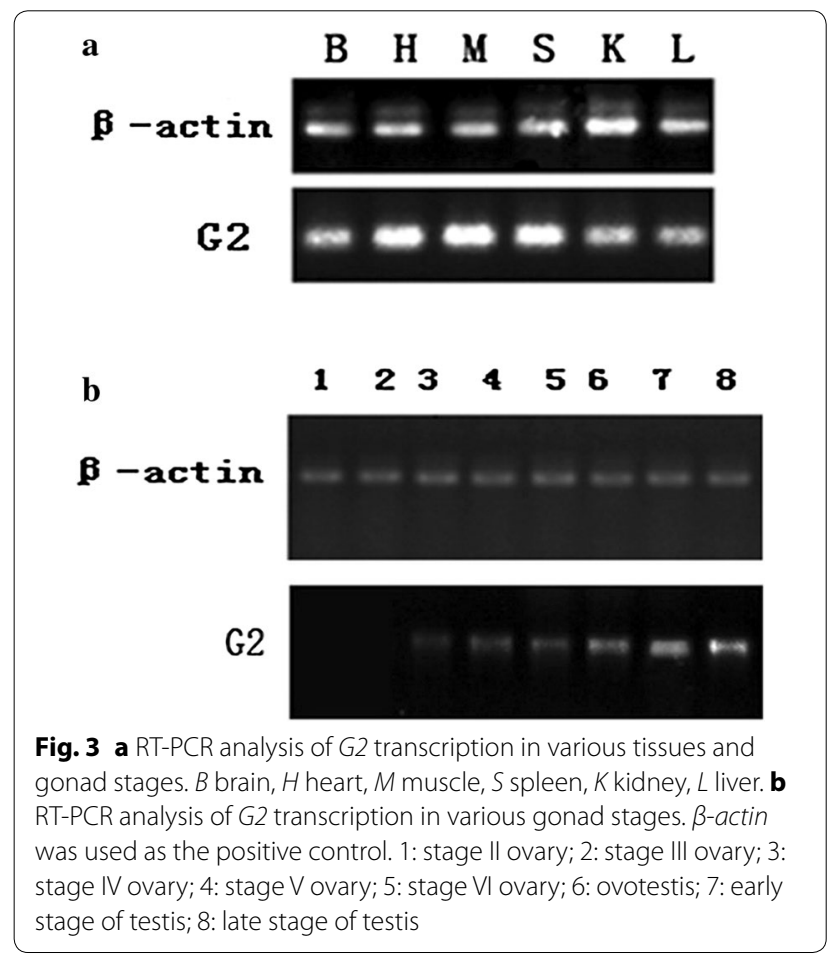

might be involved in gonad development or sex inversion in the rice field eel. Nine genes showed strong levels of homology with known genes, whereas the others were hypothetical genes. Based on our results, we propose that the ACP-DDRT-PCR technique is suitable for the screening of DEGs.

Of the five hypothetical genes, we found that the transcription of $G 2$ was much higher in the ovotestis than the ovary. Therefore, we cloned G2 and performed semiquantitative RT-PCR, real time PCR and in situ hybridization to analyze transcription patterns. Signal peptide prediction showed that $G 2$ is a non-classical secreted protein gene. According to previous reports (Zhang et al. 2009), most non-classical secreted proteins have high levels of biological activity. Semi-quantitative RT-PCR and real time PCR analysis showed that G2 transcriptional expression was low in the stage II and III ovaries, but expression was higher in the stage IV ovary and during the later stages of gonad development. We obtained the converse results with regards to the expression profiling of the JUK1 gene (Xiao et al. 2010), The c-Jun N-terminal kinases (JNKs) are members of the mitogen-activated protein kinase family. Their functions in regulating animal development have been well studied in both invertebrates and vertebrates. On the basis of Xiao's research, JNK1 plays an important role in sexual reversal of the rice field eel. In a previous paper (Liu 2009), a similar expression pattern was found during sex inversion of the rice field eel, whereby P450arom was predominantly expressed in the ovary, much less in the ovotestis, and barely in the testis. Conversely, P45011 $\beta$ was markedly up-regulated at the onset of testicular development. Steroids play an

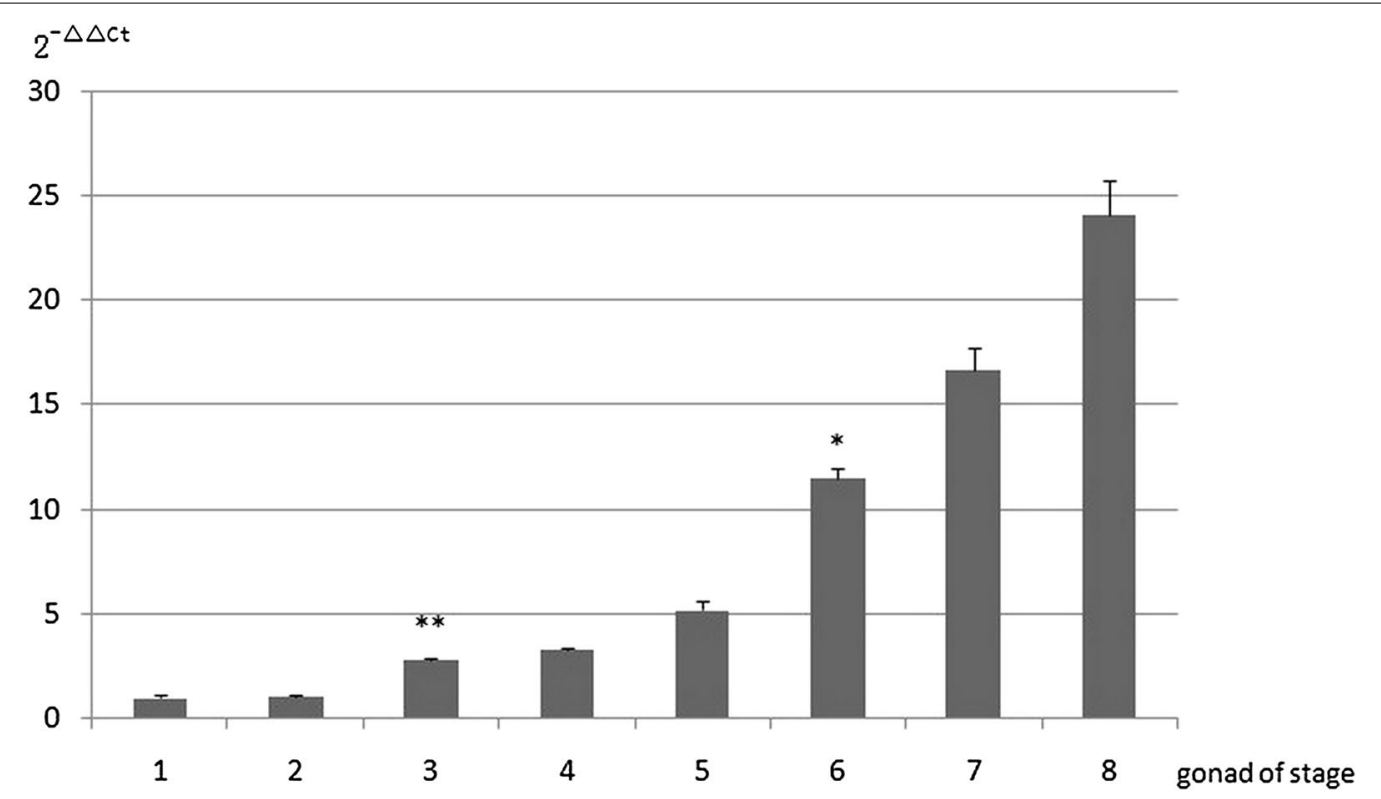

Fig. 4 Real time RT-PCR analysis of G2 transcription expression during various gonadal stages. 1: stage II ovary; 2: stage III ovary; 3: stage IV ovary; 4: stage $\mathrm{V}$ ovary; 5 : stage VI ovary; 6: ovotestis; 7: early stage of testis development; 8: late stage of testis development. Asterisk and double asterisk symbol indicate significantly different compared to the former group $\left({ }^{*} P<0.05\right.$ and ${ }^{*} P<0.01$, respectively) 
1 acatggggagaaaagggcttgtgatcagcgaatttctttattacttttcacggaagtga

60 gaggaaacctttgaaccgtaaac

83 ATG ACC TGG CCT GGA ACT GAT GGT GAG CGC GCT GCA GTC GTC AGC

$\begin{array}{lllllllllllllllll}1 & \mathrm{M} & \mathrm{T} & \mathrm{W} & \mathrm{P} & \mathrm{G} & \mathrm{T} & \mathrm{D} & \mathrm{G} & \mathrm{E} & \mathrm{R} & \mathrm{A} & \mathrm{A} & \mathrm{V} & \mathrm{V} & \mathrm{S} & 15\end{array}$

128 CTG TGG GGA AAG CTC GAC GCG GGA GCA GTT GGG GCC GAG GCT CTG 172

$\begin{array}{lllllllllllllllllllllll}16 & \mathrm{~L} & \mathrm{~W} & \mathrm{G} & \mathrm{K} & \mathrm{L} & \mathrm{D} & \mathrm{A} & \mathrm{G} & \mathrm{A} & \mathrm{V} & \mathrm{G} & \mathrm{A} & \mathrm{E} & \mathrm{A} & \mathrm{L} & & 30\end{array}$

173 CGC AGG CTT CTG ATT GTG TAT CCA TGG ACT CAG AGA TAC TTC GCT 217

$\begin{array}{llllllllllllllllll}31 & \mathrm{R} & \mathrm{R} & \mathrm{L} & \mathrm{L} & \mathrm{I} & \mathrm{V} & \mathrm{Y} & \mathrm{P} & \mathrm{W} & \mathrm{T} & \mathrm{Q} & \mathrm{R} & \mathrm{Y} & \mathrm{F} & \mathrm{A} & 45\end{array}$

218 TCA TTT GGT GAC CTG TCC AGC GAT GCC GCC ATC GCC GGG AAC CCG 262

$\begin{array}{llllllllllllllllll}46 & \mathrm{~S} & \mathrm{~F} & \mathrm{G} & \mathrm{D} & \mathrm{L} & \mathrm{S} & \mathrm{S} & \mathrm{D} & \mathrm{A} & \mathrm{A} & \mathrm{I} & \mathrm{A} & \mathrm{G} & \mathrm{N} & \mathrm{P} & 60\end{array}$

263 AAG GTG GCC GCC CAC GGC AAG GTT GTG ATG GGT GGG CTG GAT AAA 307

$\begin{array}{lllllllllllllllll}61 & \mathrm{~K} & \mathrm{~V} & \mathrm{~A} & \mathrm{~A} & \mathrm{H} & \mathrm{G} & \mathrm{K} & \mathrm{V} & \mathrm{V} & \mathrm{M} & \mathrm{G} & \mathrm{G} & \mathrm{L} & \mathrm{D} & \mathrm{K} & 75\end{array}$

308 GCA GTG AAG CAC ATT GAT GAC ACC GCC AGC GCC TTC AAG AGC CTG 352

$\begin{array}{llllllllllllllllll}76 & \text { A } & \text { V } & \text { K } & \text { H } & \text { I } & \text { D } & \text { D } & \text { T } & \text { A } & \text { S } & \text { A } & \text { F } & \text { K } & \text { S } & \text { L } & 90\end{array}$

353 AGT ACG ATG CAC TCT GAG AAG CTC CAT GTG GAC CCT GCC AAC TTC 397

$\begin{array}{llllllllllllllllll}91 & \mathrm{~S} & \mathrm{~T} & \mathrm{M} & \mathrm{H} & \mathrm{S} & \mathrm{E} & \mathrm{K} & \mathrm{L} & \mathrm{H} & \mathrm{V} & \mathrm{D} & \mathrm{P} & \mathrm{A} & \mathrm{N} & \mathrm{F} & 105\end{array}$

398 CAT AAC TTC GCC AAC GTC ATC TCT GTG GTT GTG GGT TCC AAG TGT 442

$\begin{array}{lllllllllllllllll}106 & \mathrm{H} & \mathrm{N} & \mathrm{F} & \mathrm{A} & \mathrm{N} & \mathrm{V} & \mathrm{I} & \mathrm{S} & \mathrm{V} & \mathrm{V} & \mathrm{V} & \mathrm{G} & \mathrm{S} & \mathrm{K} & \mathrm{C} & 120\end{array}$

443 GGC TCC GCA TAC ACC CCT GAG GTC CAG GCG GCC TTT GAG AAG TTC 487

$\begin{array}{llllllllllllllllll}121 & \mathrm{G} & \mathrm{S} & \mathrm{A} & \mathrm{Y} & \mathrm{T} & \mathrm{P} & \mathrm{E} & \mathrm{V} & \mathrm{Q} & \mathrm{A} & \mathrm{A} & \mathrm{F} & \mathrm{E} & \mathrm{K} & \mathrm{F} & 135\end{array}$

488 CTG GAA GTG GTC GTC CAT GCC CTG AGC AAA CAG TAC CAC TGA 529

$\begin{array}{llllllllllllllll}136 & \mathrm{~L} & \mathrm{E} & \mathrm{V} & \mathrm{V} & \mathrm{V} & \mathrm{H} & \mathrm{A} & \mathrm{L} & \mathrm{S} & \mathrm{K} & \mathrm{Q} & \mathrm{Y} & \mathrm{H} & * & \\ \end{array}$

530 gagtccctacagtcgtgcagcagtcatacaagtgcttttgaaatgactgttgtatct 586

587 gtgtcgacatatcaaataaaactaaactgagcctaaaaaaaaaaaaaaaaaaaaa 643

644 aaaaaaa

Fig. 5 Nucleotide sequence and amino acid sequence of G2.The $5^{\prime}$ and $3^{\prime}$ untranslated regions are in lower cases; the polyadenylation signal (AATAAA) is bold and boxed

important role in the sex reversal of hermaphroditic teleosts. More research needs to assess whether G2 is related to steroid secretion or the regulation of steroidogenic genes. In addition, G2 transcription was detected in the brain, heart, muscle, spleen, kidney and liver. Several papers have reported the gene that have this type of expression profile may be involved in gonadal differentiation (Yu and Tang 2008; Wang et al. 2003). Sex differentiation and development are complex, the regulation of sexual differentiation and sex change processes involves coordinated interactions between genetic, hormonal and environmental factors (Devlin and Nagahama 2002). The 
number of genes known to be involved in sexual differentiation and inversion in teleosts is increasing (Wu et al. 2010). The purpose of our study was to isolate a sex-determining gene, and the current findings shed light on sex differentiation and sex change in the rice field eel.

\section{Conclusion}

We used ACP DDRT-PCR to analyze DEGs between the stage IV ovary and ovotestis of the rice field eel. We identified 14 DEGs that could be involved in gonad development or sex inversion. Of these, nine genes have strong homology with known genes, whereas the others are hypothetical genes. One of these hypothetical genes, G2, showed higher transcription in the ovotestis than in the ovary. We cloned G2 and used semi-quantitative RTPCR, real time PCR to analyze its expression. G2 may play a role in the sex inversion process or testis development in the rice field eel.

\section{Authors' contributions}

XC Qu conceived and designed the experiments; JY Jiang and C Cheng performed the experiments; XC Qu and JY Jiang and C Cheng analyzed the data; L Feng and QG Liu contributed reagents/materials/analysis tools; JY Jiang wrote the paper. All authors read and approved the final manuscript.

\section{Author details}

${ }^{1}$ College of Fisheries and Life Sciences, Shanghai Ocean University, Shanghai 201306, China. ${ }^{2}$ College of Life Sciences, Guangxi Normal University, Guilin 541004, China. ${ }^{3}$ Key Laboratory of Ecology of Rare and Endangered Species and Environmental Protection, Ministry of Education, Guangxi Normal University, Guilin 541004, China.

\section{Acknowledgements}

This work was supported by grants from the Ministry of Agriculture, Science and Technology Education Department (201003076), Shanghai Education Committee Foundation (S30701) and Shanghai University Knowledge Service Platform, Shanghai Ocean University Aquatic Animal Breeding Center (ZF1206).

\section{Competing interests}

The authors declared that they have no competing interests.

Received: 24 September 2015 Accepted: 18 November 2015

Published online: 01 December 2015

\section{References}

Alam MA, Kobayashi Y, Horiguchi R, Hirai T, Nakamura M (2008) Molecular cloning and quantitative expression of sexually dimorphic markers Dmrt1 and Foxl2 during female-to-male sex change in Epinephelus merra. Gen Comp Endocrinol 157:75-85

Angelopoulou R, Lavranos G, Manolakou P (2012) Sex determination strategies in 2012: towards a common regulatory model. Reprod Biol Endocrinol 22:10-13

Baroillier JF, Guigen Y, Fostier A (1999) Endocrine and environmental aspects of sex differentiation in fish. Cell Mol Life Sci 55:910-931

Chan STH, Phillips JG (1967) The structure of the gonad during natural sex reversal in Monopterus albus (Pisces: Teleostei). J Zool 151:129-141

Chu ZJ (2011) Effects of estradiol valerate on steroid hormones and sex reversal of female rice field eel, Monopterus albus (Zuiew). J World Aquac Soc 42:96-104

Debouck C (1995) Invited commentary: differential display or differential dismay? Curr Opin Biotechnol 6:597-599
Devlin RH, Nagahama Y (2002) Sex determination and sex differentiation in fish: an overview of genetic, physiological, and environmental influences. Aquaculture 208:191-364

He Z, Wu YS, Xie J, Wang TX, Zhang LH, Zhang W (2012) Growth differentiation factor 9 (Gdf9) was localized in the female as well as male germ cells in a protogynous hermaphroditic teleost fish, rice field eel Monopterus albus. Gen Comp Endocrinol 178:355-362

HerpinA Schart M (2011) Dmrt1 genes at the crossroads: a widespread and central class of sexual development factors in fish. FEBS J 278:1010-1019

He Y, Shang X, Sun J, Zhang L, Zhao W, Tian Y, Cheng H, Zhou R (2010) Gonadal apoptosis during sex reversal of the rice field eel: Implications for an evolutionarily conserved role of the molecular chaperone heat shock protein 10. J Exp Zool Mol Dev Evol 314B:257-266

Huang X, Guo YQ, Shui Y, Guo S, Yu H, Cheng H, Zhou R (2005) Multiple Alternative splicing and differential expression of dmrt1 during gonad transformation of the rice field eel. Biol Reprod 73:1017-1024

Hwang IT, Kim YJ, Kim SH, Kwak Cl, Gu YY, Chun JY (2003) Annealing control primer system for improving specificity of PCR amplification. Biotechniques 35:1180-1184

Jeong HB, Park JG, Park YJ, Takemura A, Hur SP, Lee YD, Kim SJ (2009) Isolation and characterization of DMRT1 and its putative regulatory region in the protogynous wrasse, Halichoeres tenuispinis. Gene 438:8-16

Kim YJ, Kwak Cl, Gu YY, Hwang IT, Chun JY (2004) Annealing control primer system for identification of differentially expressed genes on agarose gels. BioTechniques 36:424-434

Liang P, Pardee AB (1992) Differentially display of eukaryotic messenger RNA by means of the polymerase chain reaction. Science 257:967-970

Liang P, Pardee AB (1995) Recent advances in differential display. Curr Opin Immunol 7:274-280

Liem KF (1963) Sex reversal as a natural process in the synbranchiform fish Monopterus albus. Copeia 2:303-312

Liu JK (1944) Rudimentary hermaphroditism in the symbranchoid eel, Monopterus javanensis. Sinensia 15:1-8

Liu JF (2009) Aromatase (P450arom) and 11ß-hydroxylase(P45011 $\beta$ ) genes are differentially expressed during the sex change process of the protogynous rice field eel, monopterus albus. Fish Physiol Biochem 35:511-518

Matsuda M, Nagahama Y, Shinomiya A, Sato T, Matsuda C, Kobayashi T, Morrey CE, Shibata N, Asakawa S, Shimizu N, Hori H, Hamaguchi S, Sakaizumi M (2002) DMY is a Y-specific DM-domain gene required for male development in the medaka fish. Nature 417:559-563

Nozu R, Kojima Y, Nakamura M (2009) Short term treatment with aromatase inhibitor induces sex change in the protogynous wrasse, Halichoeres trimaculatus. Gen Comp Endocrinol 161:360-364

Nakamura M, Kobayashi T, Chang XT, Nagahama Y (1998) Gonadal sex differentiation in teleost fish. J Exp Zool 281:362-372

Nelson JS (1994) Fishes of the world. Wiley, New York

Qu XC, Shang XL, Cheng C, Qu XW, Zhang Y, Zhang KY, Jiang JY (2011) Construction and analysis of gonad suppression subtractive hybridization library of rice field eel (Monopterus albus). J Fish Sci China 18:23-28

Qu XC, Jiang JY, Shang XL, Cheng C, Feng L, Liu QG (2014) Construction and analysis of gonad suppression subtractive hybridization libraries for the rice field eel, Monopterus albus. Gene 540:20-25

Qiu GF, Weber GM, Rexroad CE III, Yao JB (2008) Identification of RtGST-1, a novel germ cell-specific mRNA-Like transcript predominantly expressed in early previtellogenic oocytes in rainbow trout (Oncorhynchus mykiss). Mol Reprod Dev 75:723-730

Sinclair AH, Berta P, Palmer MS, Hawkins JR, Griffiths BL, Smith MJ, Foster JW Feischauf AM, Lovell-Badge R, Goodfellow PN (1990) A gene from the human sex-determining region encodes a protein with homology to a conserved DNA-binding motif. Nature 346:240-244

Uller T, Helantera H (2011) From the origin of sex-determining factors to the evolution of sex-determining systems. Q Rev Biol 86:163-180

Wan JS, Sharp SJ, Poirier GM, Wagaman PC, Chambers J, Pyati J, Hom YL, Galindo JE, Huvar A, Peterson PA, Jackson MR, Erlander MG (1996) Cloning differentially expressed mRNAs. Nat Biotechnol 14:1685-1691

Wang R, Cheng HH, Xia LX, Guo YQ, Hang X, Zhou R (2003) Molecular cloning and expression of Sox 17 in gonads during sex reversal in the rice field eel, a teleost fish with a characteristic of natural sex transformation. Biochem Biophys Res Commun 303:452-457 
Wu GC, Tomy S, Lee MF, Lee YH, Yueh WS, Lin CJ, Lau EL, Chang CF (2010) Sex differentiation and sex change in the protandrous black porgy, Acanthopagrus schlegeli. Gen Comp Endocrinol 167(3):417-421

Wu GC, Chiu PC, Lin CJ, Lyu YS, Lan DS, Chang CF (2012) Testicular dmrt1 is involved in the sexual fate of the ovotestis in the protandrous black porgy. Biol Reprod 86(2):41

XiangSC Hyuk S, Nam HK (2005) Identification of metaphase Il-specific gene transcripts in porcine oocytes and their expression in early stage embryos reproduction. Reprod Fertil Dev 17:6256-6631

Xiao YM, Chen L, Liu J, Liu WB, Chen HG, Zou LJ, Liu Y, Li DWC (2010) Contrast expression patterns of JNK1 during sex reversal of the rice field eel. J Exp Zool Mol Dev Evol 314B:242-256

Xiao YM, Liu Y (1995a) Study on the histology in sex changing from intersex to male of Monopterus albus. J Fish China 19:297-304

Xiao YM, Liu Y (1995b) Study on the reproductive biology of Monopterus albus (Zuiew) II: female development of Monopterus albus. Acta Sci Nat Univ Norm Hunan 18:45-51

Ye D, Lv D, Song P, Peng M, Chen YG, Guo M, Yang QW, Hu YC (2007) Cloning and characterization of a rice field eel vasa-like gene cDNA and its expression in gonads during natural sex transformation. Biochem Genet $45: 211-224$
Yoshimoto S, Ito M (2011) A ZZ/ZW-type sex determination in Xenopus laevis. FEBS J 278:1020-1026

Yu JH, TangYK Li JL (2008) Cloning, structure, and expression pattern of the $\mathrm{P}-450$ aromatase gene in rice field Eel (Monopterus albus). Biochem Genet 46:267-280

Yuan HW, Hao LP, Gong SY, Yang DQ (2012) Effects of low dietary protein level on growth and sex change in rice field eel, Monopterus albus (Zuiew). Hubei Agric Sci 51:139-142

Zhang NN, Liu X, Sun J, Wu Y, Li QW (2009) Nonclassical mechanisms of secretory protein in eukaryotic cells. Hereditas 31:29-35

Zhou L, Gui JF (2010) Molecular mechanisms underlying sex change in hermaphroditic groupers. Fish Physiol Biochem 36:181-193

Zhu XL (2010) Cloning of two vasa/PL10 genes and their expression during oogenesis in prawn (Macrobrachium nipponense). Mar Fish 32(2):132-140

\section{Submit your manuscript to a SpringerOpen ${ }^{\odot}$ journal and benefit from:}

- Convenient online submission

- Rigorous peer review

- Immediate publication on acceptance

- Open access: articles freely available online

- High visibility within the field

- Retaining the copyright to your article

Submit your next manuscript at $>$ springeropen.com 